\title{
Alumni Reflections
}

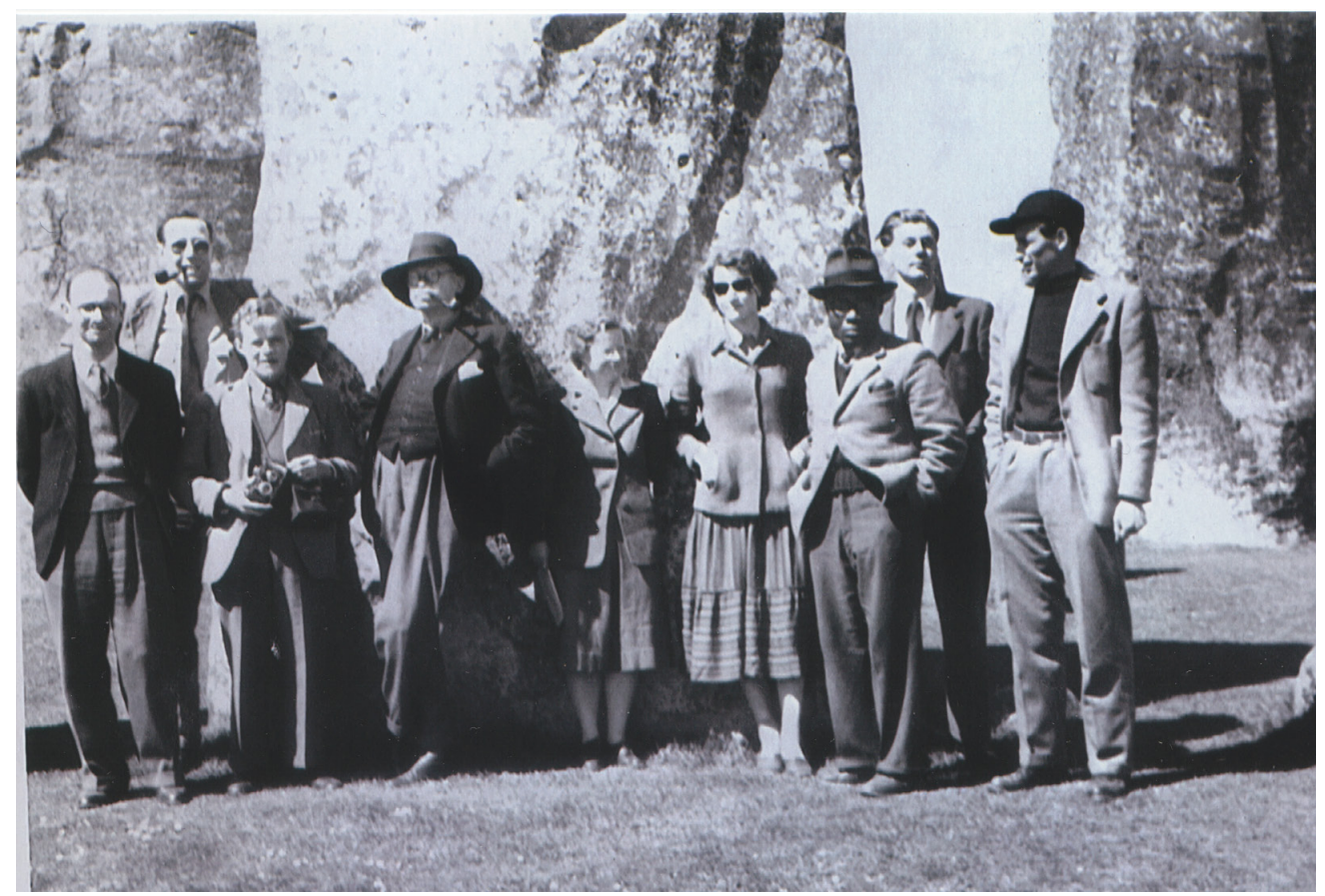

Fig. 1: Gordon Childe at Stonehenge during the Institute's spring excursion into Wiltshire, with some of the class of 1951, including Nick Thomas to his right (with camera), Paul Ashbee behind (with pipe), and Isobel Smith to his left.

\section{Nicholas Thomas \\ Postgraduate Diploma in European Archaeology 1950-52}

In 1943, how would a young schoolboy have set about preparing to become an archaeologist? "Simple, darling", my sensible and adoring mother said, "get hold of a London telephone directory and look up under A". And there it was: 'Archaeology, Institute of' (followed by an imposing West End address). We duly arranged to go and see the Secretary. On entering an enormous office, my mother and I were confronted by a person who appeared to be a sailor - blue uniform, medal ribbons, everything. But upon rising from behind an imposing desk, a skirt was immediately revealed; the person was Kathleen Kenyon, of course, the wartime Acting Director of the Institute and wearing her high-ranking Red Cross officer's uniform (see Fig. 3 in Moshenska, this volume). In answer to our request about a career in archaeology, her advice more like an order actually - was to go to Oxford and follow it by taking the Postgraduate Diploma in European Archaeology at the University of London Institute of Archaeology. She made it clear, moreover, that she expected me to take part in an excavation she was going to conduct on a bombed site in Southwark. I did what I was told to the letter, and Kath Kenyon became my mentor and friend thereafter. 
In Oxford, in 1947, where I had obediently gone to read history at Exeter College, the only British archaeology that was available to undergraduates was dirt archaeology under the inspiring leadership of Richard Atkinson, at that time an assistant keeper at the Ashmolean Museum. He had just published Field Archaeology (1946), a sort of Bible which those of us in the University's archaeological society who wanted to dig knew by heart. And at most week-ends during term we were to be found, with him, in Messrs Amey's huge gravel quarry outside Dorchester-onThames, uncovering the series of Neolithic, Bronze Age, Roman and other sites that had long been known from Major Allen's pioneering air photographs. When I went down in June 1950, henges and cursuses were all I knew about.

Happy though my years at Oxford were, it was nevertheless the prospect of the Institute of Archaeology that filled my horizon. I wrote impatiently to the Secretary, Ian Cornwall, asking when I could come up for interview. Wait until your exams are over was the response. So in June an appointment was made to introduce myself - and evidently things went well. I informed Ian in August that I had been awarded a degree and he wrote at once to congratulate me and then got straight down to business. Fees for my diploma course would amount to £23-12-6, of which $£ 2-12-6$ were to cover registration, although the University demanded an additional three guineas for registration since I had not matriculated there. 'Term begins on Wednesday, $4^{\text {th }}$ October and you should report somewhat before $3 \mathrm{pm}$. The first lecture is at that hour (on repair and preservation of pottery etc) and I will introduce you to Miss Gedye who is in charge of that course. No gowns are worn by students .... I arrived at the Institute as instructed, rang the bell at the imposing front door which presently was opened by one of the girls in the secretariat, Ida Champagne (with whom I immediately fell in love), and was conducted to Ian Cornwall. Truly I had arrived.
In 1950 there were about half a dozen of us reading full time for the Academic Diploma in European Prehistoric Archaeology, of whom Paul Ashbee and Arthur ApSimon, especially, became supportive friends. Margaret Bennett-Clark and Ken Annable, who in due course was to become my colleague and good friend at Devizes Museum, were reading for the Roman Britain diploma. And, on at least one evening each week, we were joined for an end-of-day lecture or seminar by an assortment of part-time students, including junior members of the Royal Commission on Historical Monuments.

For the most part our days revolved around the Library, reading for the weekly (or was it fortnightly?) essay. This splendid room was presided over by Joan du Plat Taylor, a gracious yet firm lady, whose assistant, jolly and socially rather superior, was Gerry Talbot.

Gordon Childe never failed to inspire or amuse, or puzzle us on the occasions when he might break into a spluttered Russian or some other obscure European language. In his crowded seminars, whether discussing our essays or just talking prehistory, we worshipped at the feet of this great, much loved, slightly remote giant of his time. So too, of course, was Professor Zeuner who, helped by Ian Cornwall and the laboratory assistant Joan Sheldon, taught us about rocks and bones, in his more regimented but very effective way. A cheroot was never far from his lips. No essays were required from him, just to pay close attention to what he was saying and be ready to be given some rock or bone with a polite request to identify it. Whether or not he had spotted my weakness here, during my last term he more than once asked me to tell the class about the same bunter pebble, as I recall it; and when I nervously attended my viva examination, behold he placed it in my shaking hands with a request for information. What a relief!

Through both Childe and Zeuner, and their colleagues, our classes - and especially our excursions into the countryside around London and further afield - unfolded the 


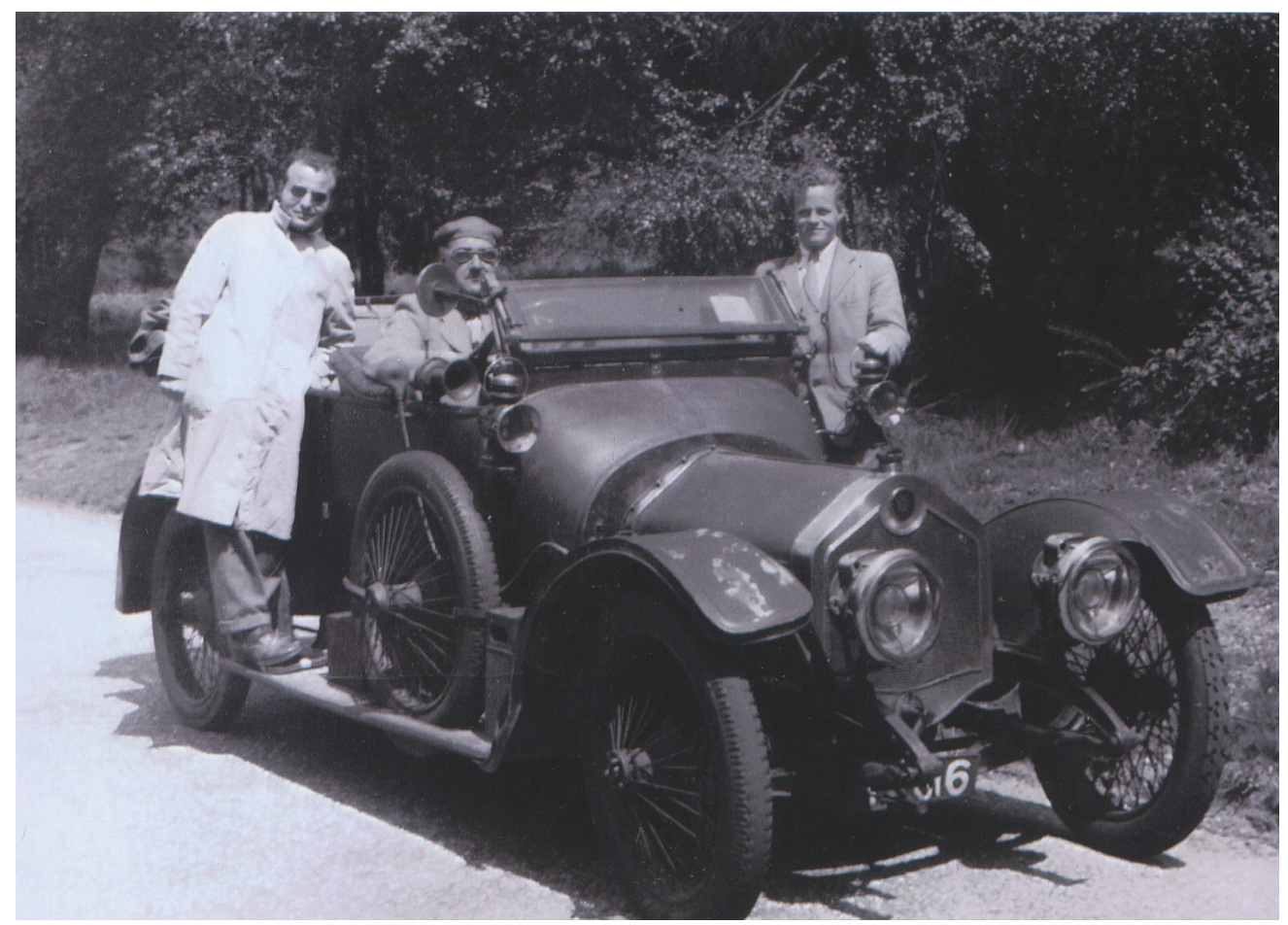

Fig. 2: Edward Pyddoke at the wheel of his 1909 Crossley open tourer, during an Institute excursion into Surrey (1951), with Nick Thomas (right) and fellow student Nick Dopulos (Detroit, USA) (photo: Paul Ashbee).

mysteries of our natural environment and the ways in which it had affected man or been affected by him. One day, on Combe Hill above Jevington, in East Sussex, I walked over my first causewayed camp. I became acquainted with Stonehenge and the evocative barrow cemeteries which surround it during a strenuous week-end under Childe's leadership (Fig. 1). Childe and Edward Pyddoke (the Institute Secretary in succession to Ian Cornwall) provided transport on some of these occasions. At all costs it was essential to avoid being invited to travel with Childe who had little control over his highpowered Ford, relying mainly on the perceptions and skills of other motorists to get out of his way. The competition was to obtain a lift with Pyddoke. Reputedly a pre-war racing motorist, he guided his 1909 Crossley open tourer at noisy speed but, we judged, in complete safety (Fig. 2).
These distinguished scholars gave us the academic theory and tangible background to European prehistory. What sticks in the memory and gave me such delight was the emphasis they placed on material culture. It was in response to this that I was to devote my working life as a museum curator to the preservation and public explanation of man-made things. Lessons on flint and stone-working technology were given by Zeuner, Cornwall, Waechter and Childe himself who, charmingly, used a potato and table-knife to demonstrate the mysteries of core and blade production. Using the Institute's fine teaching collections, some of us were in the habit of spending an occasional hour describing some odd implement or other to the critical audience of our fellow students, in preparation for the day when - we all hoped - we would be teaching others. Ancient ceramic technology also exercised our budding archaeologi- 
cal enthusiasms. A well-known studio potter, Mike Rawson, showed us how to make pots by coiling and introduced us to the kickwheel which was kept in the basement.

What set the Institute apart from the small number of centres for archaeological studies in the UK at that time was its teaching of conservation. It formed the logical complement to the emphasis on material culture in the diploma courses. The department was available to outside students as well; indeed, it was the constant flow of people attending whatever courses were on offer that so enhanced our learning experience. Ione Gedye, who directed conservation teaching, introduced us to plaster-of-Paris for pot restoration, electrolysis for cleaning iron and various chemicals for doing the same to objects of copper alloy. The happy atmosphere in which Ione and her colleagues taught us induced me to spend at least an hour there each week, potrepair being one of my peculiar delights.

Knowledge of photography was regarded as an essential part of our course. In a basement, under the watchful and rather glad eye of M.B. Cookson - or 'Cookie' - we struggled to emulate his great skill with a plate camera. It was black-and-white only, and never with a miniature camera. We did everything, whether it was making sure that the back of the camera was upright, or spending an airless session in the dark-room trying to develop our miserable results. Mrs Conlon - we never knew her first name - helped us along and kept Cookie in order.

Drawing and surveying was another way to learn to record the past. In Harry Stewart the Institute possessed an ace draughtsman. Our sessions outside armed with tapes, planetables, ranging rods and the like, attempting to put the footprint of the rambling St John's Lodge down on paper, usually failed to come together, but it was a start. And it afforded a welcome break from library books. My only regret is having come away with the feeling that we never took seriously enough the gentle ministrations of the quiet Scotsman who was so skilled at what he did.
The slightly war-torn Regent's Park building that was St John's Lodge provided a sympathetic setting for what was a community united and enthused by a fascination for the past. You were as likely to rub shoulders with a Kenyon or a Mallowan as you were with students from all parts of the world. You could attend any formal lecture, even if it lay outside your particular course. Kath Kenyon let me into her lectures as long as I was prepared to project her $\left(3^{1 / 4} \times 3^{1 / 4}\right.$ in) slides. In basement rooms, you could watch the fragments of painted wall-plaster from the Lullingstone Roman villa being pieced together, or help Kenyon attempt to classify the North African Roman coarse wares from her Sabrata excavations. And if you were specially privileged you could see some of the royal products from Sir Max Mallowan's work at Nimrud, in Iraq. In those days, certain rooms at the Institute seemed to have been awash with the delectable ivories which he had found.

As if this crowded learning process was not exacting enough, we were encouraged to get experience in giving lectures whenever the opportunity arose, with the aid of the Institute's comprehensive collection of lantern slides. In my last year, with the arrogance of an Oxford background, I took over an extramural class at the City Literary Institute from Leslie Grinsell when, halfway through, he was appointed to compile a gazetteer of barrows for the Victoria County History of Wiltshire. We were also encouraged to get as much experience in excavation as possible, usually as supervisors of rescue excavations for the Ministry of Works.

The sense of comradeship at the Institute extended from the top. At tea and coffee breaks everyone met in the staff room. If it was your birthday you had to bring along something tasty to mark the occasion. "Ah, cake!", I can hear Childe exclaiming with delight on entering the room for his tea. Many of us, staff and students lunched together daily in the subsidised refectory at Bedford College, just a bowshot around the 


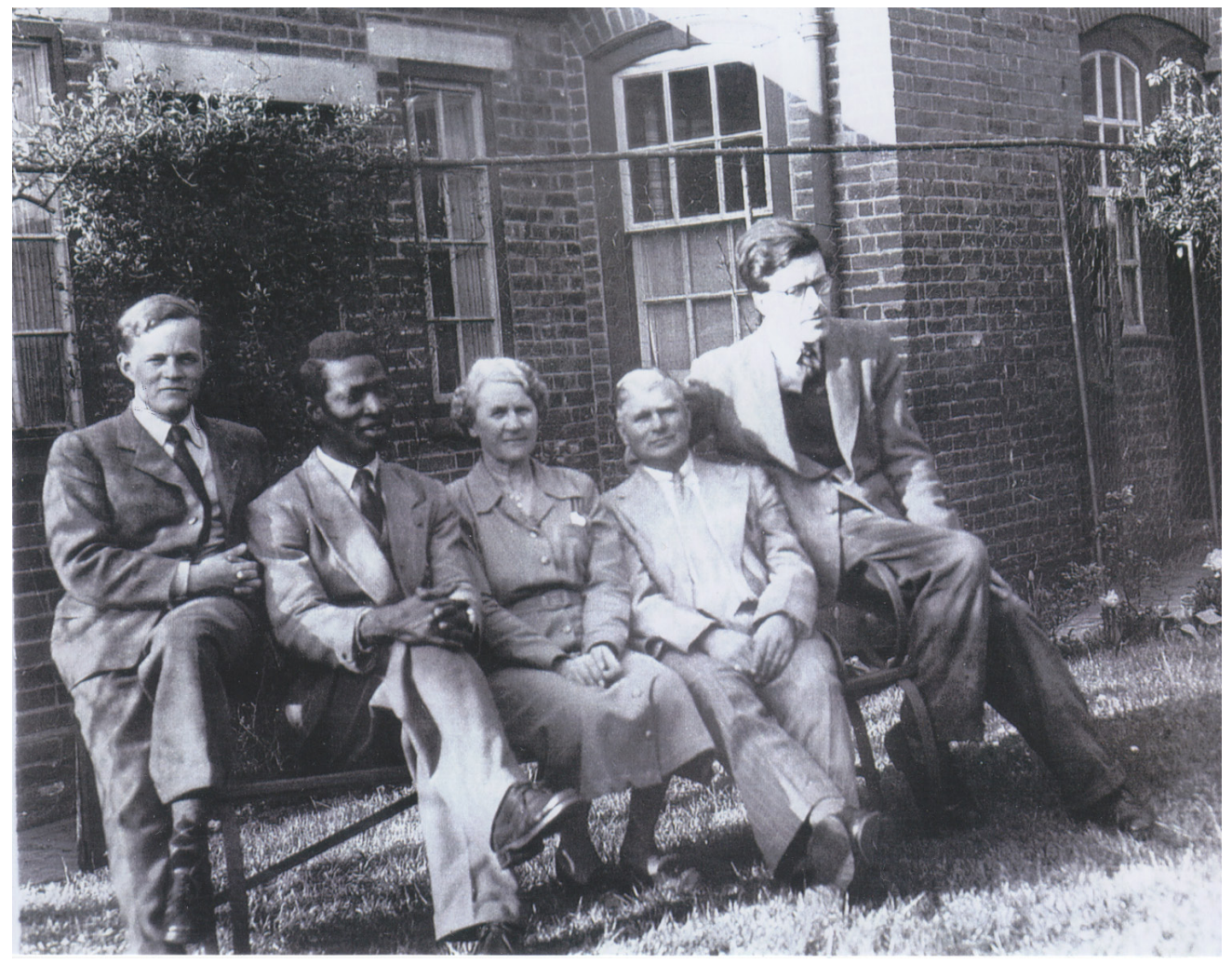

Fig. 3: Staff at Devizes Museum, Wiltshire (April 1954). Left-right: Nicholas Thomas (Curator); Justus Akeredolu (short-term attachment), Institute of Archaeology conservation student, from Nigeria; Mrs and Mr Cole (Caretaker and part-time Handyman); and Ken Annable (Assistant Curator).

Inner Circle. When my father died unexpectedly in my first year, creating the possibility of having to leave diploma-less and earn my keep, Childe immediately obtained grant-aid from the University so that I could continue; and Collin and Margaret Bowen took me in as a free lodger until my mother was able to provide a new home in London. Pyddoke kept a fatherly eye on what we were to do when we had obtained our diplomas, and it was he who drew my attention to an advertisement for the curatorship of Devizes Museum, where I became its first paid curator (Fig. 3). On my office wall I proudly hung my framed Diploma - awarded 'with a mark of distinction'. Thank you, Gordon Childe and all our other teachers at the University of London Institute of Archaeology!

\section{Oliver Hutchinson}

\section{BA Archaeology 2002-05}

Being asked to reflect on my experience of the Institute of Archaeology was in all honesty initially something of a shock. It has been eight years since I graduated and such a passage of time more often than not can cloud your memory; it can make you forget details. Sitting down to write this piece however, I had no problem recalling everything about those three years and the environment and people that shaped them.

I graduated with a BA in Archaeology, a degree that enabled me to explore my deep curiosity for the wider discipline whilst offering me the opportunity to focus on particular interests. Through lectures, seminars, tutorials and a fantastic library I learnt how to 


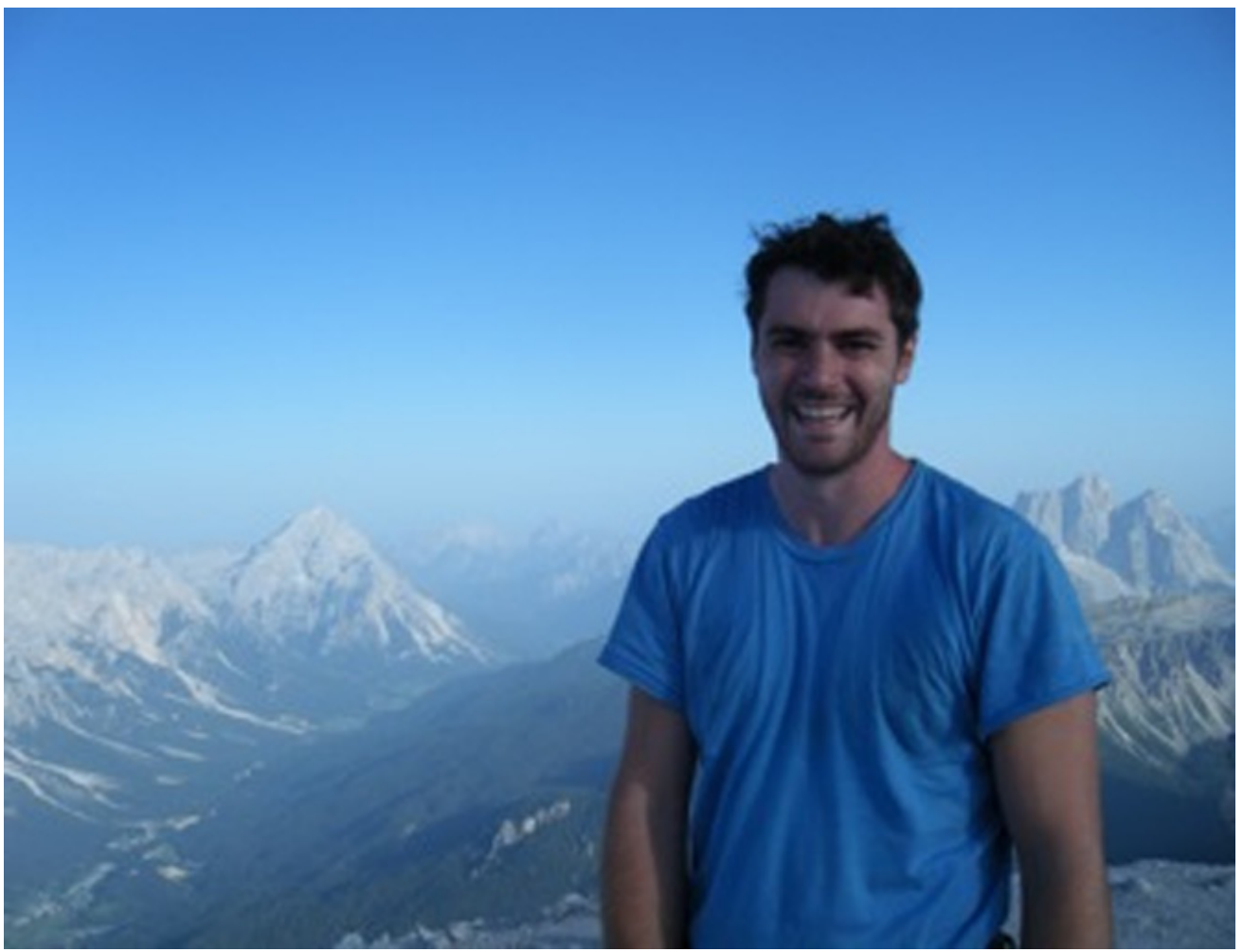

Fig. 4: Oliver Hutchinson.

research, question, discuss and share ideas. I learnt to develop a methodical approach to my work that led to me to understand the importance of asking the right questions as well as seeking the answers, skills that will continue to underpin my professional work ethic.

My first-year experience at 'Primtech' and Barcombe Roman Villa gave me the archaeological field skills to travel beyond the UK to dig. I feel very fortunate to have been able to develop my degree around the world at a number of incredible sites. In my first year, I travelled to Lamanai working to excavate and understand a royal compound deep in the jungles of Belize. In my second year, I travelled to Romania and the vast Roman site of Noviodunum, where I spent a month surveying and mapping various features and structures. In my final year, I spent a month excavating at the Belmont site in the British Virgin Islands, as well as time in Buck- fastleigh, Devon. I will never forget these unique experiences and my pride in helping to further our knowledge of these sites.

Presently, I work as a freelance consultant and project developer within all tiers of government, concentrating on environmental and low carbon issues. There is no question that my time at the Institute instilled me with the confidence, skills and belief that breaking away from the crowd and thinking a little differently would help me to succeed when setting up on my own. It was a tough decision to make, but it was certainly the right one and it has led to me having a very varied working life. I have assisted in the development of regional climate-change planning in the UK, worked alongside and visited European partners to share learning, technology and policy approaches to climate change and supported local MPs to develop new and innovative projects in their constituencies. I also work with pupil groups of 
all ages in 45 schools empowering them to understand and benefit from adapting their behaviours to support their local environment. All of this work has required the skills and approaches I developed at the Institute.

Recently, I found myself on Torrington Place and I couldn't fail to notice a simple phrase sitting proudly in huge lettering, spanning the ground-floor windows of the Engineering building: 'Change the world'. It makes me proud to know that UCL developed my ability to give that a shot.

\section{Louisa Gilbert}

\section{BSc Archaeology 2007-10}

I left the doors of the Institute of Archaeology in 2010 unsure what I wanted to do next. I was sure though that I was not going to be an archaeologist. Whilst valuing the time I spent at the IoA and hugely enjoying my BSc, I would not have been suited to a life in academia and, if I am completely honest, being in the trench was far from my undergraduate 'best bits'. My trowel has since become a lost artefact, somewhere beneath West Dean's top soil, and I write this now from my desk in the BBC's Specialist Factual Television department, where I work as a researcher.

Television research requires you to find and develop information so it can be written into scripts for the screen. I liaise predominantly with academics about their research and work out how best to communicate what is happening in the field in a television programme. I am freelance, as most people working in TV are - working across different programmes and different subjects. Currently, I cover science subjects and spend many hours scratching my head, bent over science research papers and speaking to scientists, essentially (for want of a better word) translating their information into a format deliverable to an audience at 7pm on BBC 1, who (as I was told by my Producer on my first day here) "will probably only be half watching as it is tea-time".

My archaeology degree has had varying degrees of influence in making me an attrac-

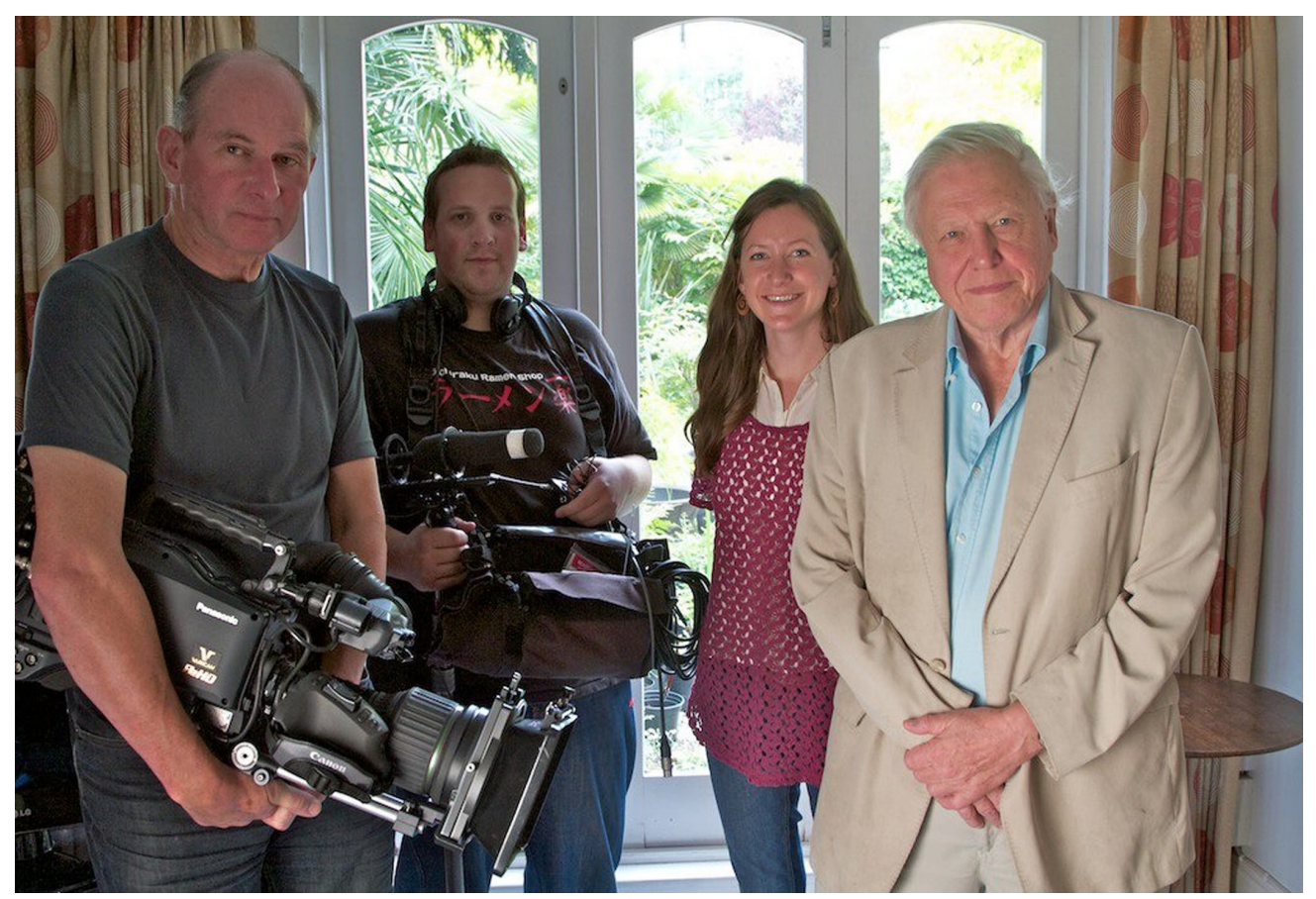

Fig. 5: Louisa Gilbert, with Sir David Attenborough, filming for the BBC. 
tive candidate for jobs and also in helping me to complete the tasks within a job role. I change jobs every few months, so I am regularly going through the interview process. Regardless of the role I am going for, saying I have an archaeology degree never fails to turn into a talking point in an interview and I have found that, regardless of their academic background, people are genuinely interested in what I studied. Having done a degree that gave me the opportunity to travel and get experience beyond writing essays, I believe stood me in good stead when I first graduated, and the fact that archaeology encompasses so many other subjects - social behaviour, landscapes, artefacts - means that the discipline of studying it allows you to apply yourself in other areas. My next job will be working on a series for BBC 2 about Stonehenge, but in the past I have worked on natural history, science and social behaviour programmes.

The lifestyle of intensively working in one area of research that takes you out of the library and office and into the field is similar. I will spend weeks or months preparing for a shoot; where we collect what we need to come back and turn into a programme is, I suppose, a way of working similar to how archaeologists enter the field. It goes without saying that the discipline of research has been crucial for me to do my job.

Working in television has been fantastic in that you are able to experience such a huge amount that I think would be next to impossible otherwise. You travel all over the world; you meet leading experts in fascinating subjects and become immersed and knowledgeable in subjects you would otherwise know nothing about. It is a unique job and one I intend to continue working in for a while. That said, it is not all great; in fact, some shoots I have been on have been horrible and others completely ridiculous (I recently spent 15 hours in a freezing cold, concrete tunnel under Kielder reservoir in
Northumbria folding a length of paper $3 \mathrm{~km}$ long in an attempt to break a world record - which we didn't). The continuous days of long hours can be close to suicidal and it is an incredible competitive industry with some big egos; in the last year I shudder at the number of times I have heard the phrase 'sink or swim'. It is a challenging job that has excellent pay-offs, in what you have access to do and see, but I would be lying if I said I loved every minute.

Undergraduates in more recent years are under a pressure to justify their degree and also have to seriously consider if it is worth undertaking. It is not only the cost of doing it, but also there is no guarantee it will help you get a job when you graduate. It was the right decision for me and I truly believe that the elements of my BSc Archaeology have contributed to my handling different roles in my career. In having experience in archaeological field-work, I've been prepared for outdoor Natural History films, including three David Attenborough programmes, the analytical nature of excavation and data analysis certainly helps me with my current position at BBC Science, my experience in museums and heritage organisations prepared me as a researcher on ITV and English Heritage's series, 'Britain's Secret Homes'. During a panel interview for BBC Specialist Factual, I was asked on the spot to pitch an idea for the next Science series and turned for inspiration to the experimental archaeology that I had based my dissertation on - I got the job.

UCL is a fantastic institution to have studied at and its standing among the world's leading universities places its alumni in advantageous positions. With the IoA as the leading academic centre in its field, sitting within an institution like UCL, I feel proud to centre and bold the font that states my degree on my CV and know that I am amongst an eclectic mix of talented alumni who do the same. 
How to cite this article: Thomas, N, Hutchinson, $\mathrm{O}$ and Gilbert, L 2013 Alumni Reflections. Archaeology International, No. 16 (2012-2013): 140-147, DOl: http://dx.doi.org/10.5334/ai.1604

Published: 24 October 2013

Copyright: (c) 2013 The Author(s). This is an open-access article distributed under the terms of the Creative Commons Attribution 3.0 Unported License (CC-BY 3.0), which permits unrestricted use, distribution, and reproduction in any medium, provided the original author and source are credited. See http://creativecommons.org/licenses/by/3.0/.

] $\mathbf{u}[$ Archaeology International is a peer-reviewed open access journal

] $\mathbf{u}\left[\begin{array}{l}\text { Archaeology International is } \\ \text { published by Ubiquity Press }\end{array}\right.$ 